\title{
Divided Nation on Records: The Transnational Formation of Finnish Popular Music During the Gramophone Fever
}

\section{Marko Tikka and Sami Suodenjoki}

\section{INTRODUCTION}

The accordion is just the thing. I know. Your nationality doesn't appreciate anything else!!

With these words, an American sales director for a multinational record company described the musical preferences of Finns to an interviewer in 1927. He knew what he was talking about. The accordion was the most popular instrument for many European emigrant groups in contemporary North America: not only for the Finns but also for the Italians, Irish,

${ }^{1}$ Yrjö Sjöblom, "You have to educate them yourself!" Kalevainen 16 (1928), 46.

M. Tikka • S. Suodenjoki $(\bowtie)$

Tampere University, Tampere, Finland

e-mail: sami.suodenjoki@tuni.fi

(C) The Author(s) 2021

V. Kivimäki et al. (eds.), Lived Nation as the History of Experiences and Emotions in Finland, 1800-2000, Palgrave Studies in the History of Experience, https://doi.org/10.1007/978-3-030-69882-9_6 
Germans, Scandinavians, and Slavs. ${ }^{2}$ Yet the director's words not only mirrored but also shaped the state of affairs, because his company had enormous influence on the direction of popular music in Finnish America and soon thereafter also in Finland. At the time of the interview, the recording industry had not yet started in Finland, but the market for popular music records in the Finnish language was already mushrooming. During the following two years of "gramophone fever," over a million gramophone records were imported to Finland, and around a quarter of them contained Finnish-American popular music. These records played a crucial role in molding consumer tastes.

In this chapter, we explore how imported gramophone records tapped into the lived experiences of the nation among Finnish audiences and shaped their experience of popular music in the late 1920s. We focus on records, which were recorded for Finnish audiences in America and Europe and examine how these records outlined the transnational and local elements of what was to be known as Finnish popular music. By doing so, we engage with a spatial turn in the history of nationalism that involves attentiveness to the impact of transborder flows and movements on nation formation and national identities. ${ }^{3}$ Furthermore, we explore how the spread of the imported records reflected the deep political divides of the newly independent nation-state, which had seceded from Russia in 1917 and witnessed a bloody Civil War the following year. We argue that popular music was an important medium through which people lived out the nation in their everyday practices and that gramophone records, by changing these practices and the idea of popular music, could also influence how people experienced the nation.

As a theoretical tool, we employ the concept of communities of experience, which can refer to almost any social or imagined communities formed around shared experiences. Studying these communities is possible without explicit focus on emotions, but the concept is nevertheless close to

\footnotetext{
${ }^{2}$ James Leary, "Crossover accordionists," in Squeeze this! A Cultural History of the Accordion in America, ed. by Marion Jacobson (Illinois: Illinois University Press, 2012), 118-21; Helena Simonett, "Introduction," in The Accordion in the Americas. Klezmer, Polka, Tango, Zydeco and more, ed. by Helena Simonett (Illinois: Illinois University Press, 2012), 12-13.

${ }^{3}$ Eric Storm, "The spatial turn and the history of nationalism: Nationalism between regionalism and transnational approaches," in Writing the History of Nationalism, ed. by Stefan Berger \& Eric Storm (London: Bloomsbury, 2019), 215-37.
} 
Barbara Rosenwein's idea of "emotional communities." ${ }^{4}$ Communities of experience are formed by individuals who share personal or collective experiences and interpret them together in a specific context. They are dynamic, overlapping and synchronous, which means that an individual can belong to many experience communities at the same time and move between them. An individual could become part of an experience community, for example, through social status, family, neighborhood, profession or civic activity. ${ }^{5}$ In this chapter, we examine how popular music records could reinforce and shape existing experience communities related to political and class status, but we also consider whether people who were listening to the same records at the same time across the nation could be referred to as a community of experience.

The chapter spans the period from the rise of record importing to Finland, around the mid-1920s, to 1930, when the importation of records plummeted due to the global economic depression. The records under examination are from the catalogs of the British-American record company Columbia and the British Gramophone Company. ${ }^{6}$ The catalog of Columbia consists of 117 music records, which were originally produced for Finnish-American consumers in the United States and only later reissued for Finland, in 1928-30. These records contained instrumental and vocal dance music as well as comic songs, not forgetting political workingclass songs. By comparison, Gramophone's catalog for Finland included 165 records, comprising dance music but also patriotic art music, which were recorded in 1925-29, mostly in Europe. The chapter outlines key differences between these catalogues, suggesting that they were aimed at partly different audiences.

Besides analyzing the genres and content of these records, we explore their circulation and reception in Finland through digitized newspapers and periodicals. ${ }^{7}$ By using song titles as keywords, we trace where and when particular records were played and sold and how Finnish audiences responded to them. Popular songs were covered frequently in contemporary

\footnotetext{
${ }^{4}$ Barbara Rosenwein, "Worrying about Emotions in History," The American Historical Review 107:3 (2002), 842.

${ }^{5}$ In a Finnish context, see Ella Viitaniemi, "Muurarimestari Kustaa Stenman ja katumaton maailma," in Eletty historia: Kokemus näkökulmana menneisyyteen, ed. by Johanna Annola, Ville Kivimäki \& Antti Malinen (Tampere: Vastapaino, 2019), 76-7.

${ }^{6}$ The records are listed in Rainer Strömmer's Catalogue of Finnish $78 \mathrm{rpm}$ Records (Helsinki: Suomen Äänitearkisto, 2012), 23-8, 148-57.

${ }^{7}$ Digital collections of the National Library of Finland, digi.kansalliskirjasto.fi
} 
news reports and columns, whereas the advertisement sections of newspapers and journals provide ample evidence of the sales channels of recordings. As an additional source, we employ reminiscences regarding gramophone use in the 1920-40s, which are included in a survey about consumer habits preserved in the Finnish Literature Society's Archive. ${ }^{8}$

The first section of the chapter outlines the material conditions surrounding the "gramophone fever" and the main features of the popular music records sold in Finland in the late 1920s. We argue that the breakthrough of the global music industry, marked by cheap gramophones, "hit records" and their efficient marketing, changed the whole idea of popular music during this period. ${ }^{9}$ As part of this development, Finland witnessed a flux of Columbia's Finnish-American music records, which were targeted at working-class audiences and thereby had some distinctive features compared with other records on the market. Nevertheless, the second section shows that the best-selling dance-music recordings in the catalogs of Columbia and Gramophone also had certain similarities, in terms of musical style and orchestration, which helped to frame these recordings as "Finnish".

In the third section, we explore how a popular song came "sticky" with emotions as it spread across borders and confronted new audiences of different political persuasions. ${ }^{10}$ To do this, we focus on the march "Vapaa Venäjä" (Free Russia), which became a hit record in Finnish America in 1924. At the end of the decade, the imported records also boosted the popularity of Free Russia in Finland and stirred public criticism against the song for allegedly glorifying Soviet Russia. Free Russia came to embody the political divisions of the nation, as it served to reinforce the experience community of leftist workers on the one hand and stir "hot" nationalist hostility on the other. Yet the record industry also detached the Free

${ }^{8}$ Finnish Literature Society Archives (FLSA), Folklore Archive (KRA), Survey on Consumer Habits (Kulutus) 2006-7. For more extensive use of this material, see Tiina Männistö-Funk, “They Played it on Saturday Nights in a Barn’: Gramophone Practices and Self-Made Modernity in Finland from the 1920s to the 1940s," International Journal for History, Culture and Modernity 1:2 (2013), 101-27.

${ }^{9}$ For this development in the United States and Britain, see W. H. Kenney, Recorded Music in American Life: The Phonograph and Popular Memory, 1890-1945 (New York: Oxford University Press, 1999); James J. Nott, Music for the People: Popular Music and Dance in Interwar Britain (Oxford: Oxford University Press, 2002).

${ }^{10}$ For "sticky affects," see Sara Ahmed, The Cultural Politics of Emotion (Edinburgh: Edinburgh University Press, 2004). 
Russia march from a strictly political framework by making it a commodity and one "Finnish" popular music piece among others.

\section{Imported Gramophone Records as Tone Setters FOr Popular Music}

Ordinary people encountered music in various spheres of everyday life in the 1920s. In Finnish schools, the singing of patriotic and regional songs and hymns formed an important part of the curriculum. The singing of hymns was also an essential element of church services, which a considerable part of the population still attended; and it influenced the ways in which people used their singing voice in other contexts. In the events of various civic associations, collective singing was used as a means of strengthening unity and solidarity among participants. Many associations also organized dances to pull crowds to their events, even if dancing was labeled as sinful by many religious and conservative people. ${ }^{11}$ At these events, dance music was typically performed by an accordionist or a live orchestra, but the gramophone also appeared as a substitute for live music at the end of the 1920s. ${ }^{12}$ Popular music was also sometimes heard in movie theaters, where a pianist, accordionist or gramophone accompanied a silent film or entertained the audience during the reel change. Even more so than the radio, another trendy consumable of this period, the gramophone revolutionized the way people listened to music and spent their leisure time. ${ }^{13}$

The international record industry had gained ground in Finland at the beginning of the twentieth century when the Gramophone Company started to produce records specifically for the Finnish market. ${ }^{14}$ After a decade-long break caused by World War I, the Gramophone Company revived recordings for Finland in 1925. Around the same time, Finnish

\footnotetext{
${ }^{11}$ Marko Tikka \& Seija-Leena Nevala, Kielletyt leikit: tanssin kieltämisen historia Suomessa 1888-1948 (Jyväskylä: Atena, 2020), 36-41, 53-6, 68-73.

${ }^{12}$ Männistö-Funk (2013), 116.

${ }^{13}$ Radio broadcasting started in Finland in 1926 but did not become more common until the 1930s. The non-commercial, state-owned Finnish Broadcasting Company (Yleisradio) had a quite conservative music policy for a long time.

${ }^{14}$ Pekka Gronow \& Björn Englund, "Inventing Recorded Music: The Recorded Repertoire in Scandinavia," Popular Music 26:2 (2007). See also Karleric Liliedahl, The Gramophone Co.: Acoustic recordings in Scandinavia and for the Scandinavian market (Helsinki: Suomen äänitearkisto, 1977).
} 
consumers were familiarized with imported German, Swedish and AngloAmerican music records, which included modern dance-rhythm pieces with simple choruses. Together with innovations in recording technology and the spread of portable gramophones (Fig. 6.1), the appeal of modern dance music brought about a global "gramophone fever" at the end of the decade. This boom of the record industry reached Finland in 1929, when annual record sales exploded to around 1.2 million. ${ }^{15}$ According to an estimate, these records included 250,000 Finnish-American recordings manufactured in the United States and Britain specifically for Finland. ${ }^{16}$

Finland had no domestic record production before the end of the 1920 s, which meant that all the records sold were imports. Both gramophone records and gramophones were considered luxury items with high customs duties. This made these products too expensive for most Finnish consumers, whose living standard was still far below that of Western Europeans despite rapid economic growth in interwar Finland. ${ }^{17}$ However, the situation changed when the government quartered the duties on gramophones and records from the beginning of $1929 .{ }^{18}$ This decision paved the way for the explosion of record sales in Finland. ${ }^{19}$

The period of gramophone fever showed that consumers yearned for danceable "schlager" tunes with Finnish vocals. The Gramophone Company pressed the first modern dance-music recordings for Finland in 1928 and 1929 , but those were not enough to satisfy the growing demand. To fix this, two businessmen began to import Finnish-American records. One of them was English-born Charles Henry Chester, who had set up a radio and gramophone shop in Helsinki in 1925. At first, Chester sold Swedish, German and American records, but later he started to search for music better suited to Finns. As a native English speaker, he had no

\footnotetext{
${ }^{15}$ Gronow \& Englund (2007), 300; Pekka Gronow, 78 kierrosta minuutissa: Ä̈̈nilevyn historia 1877-1960 (Helsinki: Suomen Jazz \& Pop Arkisto, 2013), 93, 120-6.

${ }^{16}$ Einari Kukkonen, Oi muistatkos Emma (Helsinki: Kustannuskolmio, 1998), 111-2.

${ }^{17}$ For economic development, see Riitta Hjerppe, The Finnish Economy 1860-1965: Growth and Structural Change (Helsinki: Bank of Finland, 1989), 48-53.

${ }^{18}$ See Kansan Lehti 31 December 1928, 6. The duties on gramophones and records were again raised at the end of 1929 as a response to the rapid growth in sales. Helsingin Sanomat 5 October 1929, 3; Aamulehti 21 November 1929, 3.

${ }^{19}$ On the gramophone fever in Finland, see Peter von Bagh \& Ilpo Hakasalo, Iskelmän kultainen kirja (Helsinki: Otava, 1985); Pekka Jalkanen \& Vesa Kurkela, Suomen musiikin historia: Populaarimusiikki (Porvoo: WSOY, 2003); internationally Pekka Gronow \& Ilpo Saunio, An International History of the Recording Industry (London: Cassell, 1998), 39-41.
} 


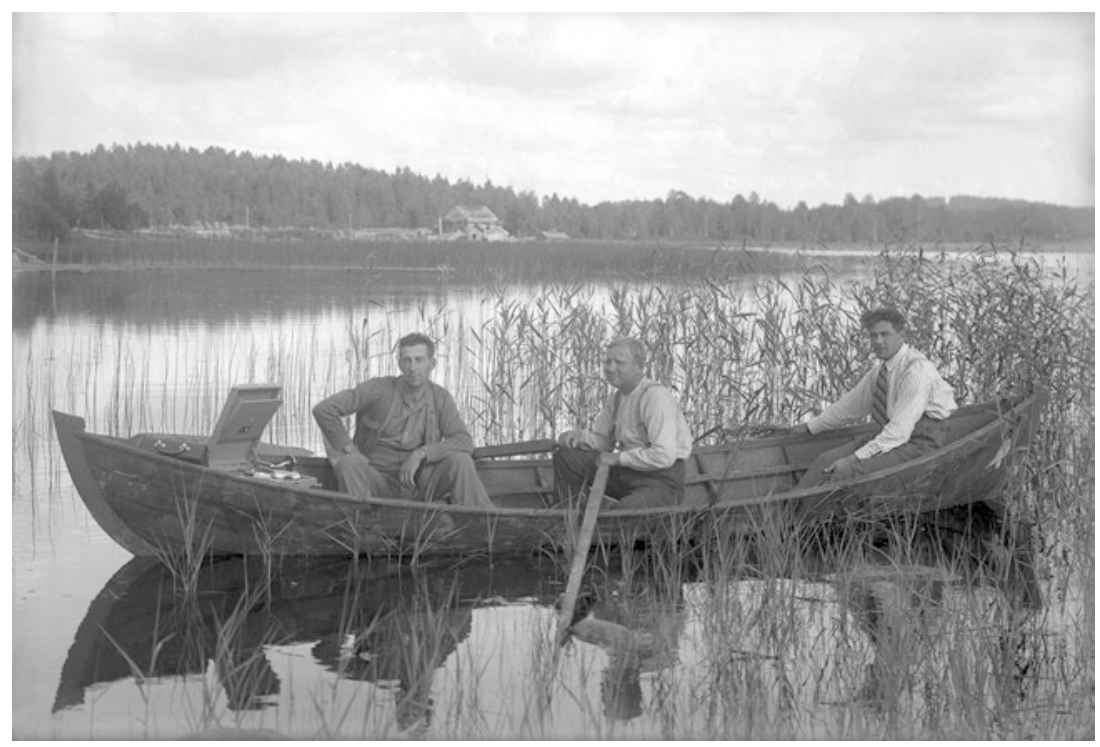

Fig. 6.1 Cheap portable gramophones enabled listening to popular music records in new settings, such as in rowboats, in the late 1920s. (Photo: Matti Luhtala, Vapriikki photo archive, Tampere)

trouble contacting the Columbia headquarters in London. ${ }^{20}$ Columbia was among the pioneers of so-called ethnic recordings in the United States, and the company had produced a considerable catalog of FinnishAmerican music during the $1920 \mathrm{~s} .{ }^{21}$ Chester negotiated a contract to distribute these records in Finland and sold them in the tens of thousands in 1928-30. Even if his motive was primarily to make money, he had a considerable indirect influence on what consumers came to understand as Finnish popular music.

\footnotetext{
${ }^{20}$ Marko Tikka, "Kuinka populaarimusiikista tuli yhteistä," Historiallinen Aikakauskirja 119:1 (2021). Another businessman Niilo E. Saarikko, later a well-known music producer, also imported Finnish-American Columbia records to Finland in the late 1920s, but much is not known about his business. On Saarikko see Pekka Gronow, "Saarikko, Niilo (1898-1979)," Kansallisbiografia, https://kansallisbiografia.fi/kansallisbiografia/henkilo/1035, accessed 9 January 2020.

${ }^{21}$ Pekka Gronow, "Ethnic Recordings: An Introduction," in Ethnic Recordings in America: A Neglected Heritage (Washington: American Folklife Center, 1982), 3.
} 
The Finnish-American records that Chester imported had their own catalog numbers, owing to which these records are easily identifiable today. Based on the number of preserved records, Chester's imports circulated widely in Finland in the late 1920s, and their impressive sales were also noted in contemporary papers. ${ }^{22}$ Overall, Chester's catalog for the years 1928-30 included 117 releases, which he had picked from Columbia's recordings that had succeeded in Finnish America and had the potential to do the same in Finland.

Table 6.1 indicates the categories of the Columbia music records imported by Chester and the releases for Finland by the other major company Gramophone between 1925 and 1929. These records fall into five categories: (1) instrumental dance music, (2) modern dance music with vocals, (3) comic songs, (4) ideological songs and (5) other music pieces. The first category, instrumental dance music, typically included traditional folk music pieces played by an accordionist or a small folk music band. Most of these pieces were familiar to Finnish listeners, as they were the kind of music that was played in dance soirées and other public dance events in Finland.

The second category of records comprised "modern dance music." This music emanated from the United States, where new dances like the

Table 6.1 Finnish-American recordings of Columbia released in Finland and the recordings for Finland by the Gramophone Company, 1925-29

\begin{tabular}{lcccc}
\hline & \multicolumn{3}{c}{ Sides (No) } & \multicolumn{3}{c}{ Sides (\%) } \\
\cline { 2 - 5 } & Columbia & Gramophone & Columbia & Gramophone \\
\hline Dance music without vocals & 63 & 36 & 26.9 & 10.9 \\
Dance music with vocals & 24 & 32 & 10.3 & 9.7 \\
Comic songs & 50 & 84 & 21.4 & 25.5 \\
Ideological music & 19 & 30 & 8.1 & 9.1 \\
Other: Concert music, operetta songs, & 78 & 148 & 33.3 & 44.8 \\
and so on & 234 & 330 & 100 & 100 \\
Total & & & & \\
\hline
\end{tabular}

The data include 117 records (234 sides) from the Columbia series 7000, 13000 and 16000 , and 165 records ( 330 sides) from His Master's Voice series AL and X, produced by Gramophone. Information on the records is based on Strömmer (2012), 23-28, 148-57

${ }^{22}$ Tuisku 30 June 1929, 7; Sulho Ranta, "Gram-, gram-, gramofooneja," Tulenkantajat 18 September 1929, 287. 
foxtrot, the turkey-trot and the one-step, had become popular in the 1910s. Supported by cheap gramophones and dance-music records, this music spread over the Western world and became the standard of modern dancing after World War I. ${ }^{23}$ As a consequence, local orchestras everywhere were trying to play foxtrots, waltzes and tangos like the AngloAmerican or European dance orchestras of Paul Whiteman, Jack Hylton or Dajos Bela. ${ }^{24}$

Finnish audiences familiarized themselves with modern dance music through popular pieces of the day like "Underneath the Russian Moon," "Alaska," "Katinka" and "Jeannine, I Dream of Lilac Time." The record company had "nationalized" these pieces simply by recording them with Finnish lyrics. ${ }^{25}$ However, the most successful modern dance-music recording in Chester's catalog was a waltz of Finnish origin, "Meren aallot" (Waves of the Sea). It sold as many as 17,000 copies in Finland. ${ }^{26}$ Waves of the Sea was performed by the trio of the American-born Finnish musician Antti Kosola and the emigrant singer Leo Kauppi (1900-38), who became famous in Finland owing to Chester's imports. ${ }^{27}$

The third category, comic songs, represented popular recording material in the early twentieth century and was featured in both catalogs under examination. The mainstream comic songs were non-political, but some Finnish-American comic songs nevertheless did include political elements such as inconspicuous references to class relations. ${ }^{28}$

The fourth category of songs, small but important, was ideological music. Nearly all the Finnish-American records in this category were performative music connected with the labor movement, including the

${ }^{23}$ Don Rayno, Paul Whiteman: Pioneer in American Music, 1890-1930, Volume I (Lanham: Scarecrow, 2003); Kenney (1999), 63-4. On recordings and dance music, see Nott (2002); Catherine Parsonage, The Evolution of Jazz in Britain, 1880-1935(London: Routledge, 2005).

${ }^{24}$ Gronow (2013), 133-5. For Sweden, see Dan Malmström, Härligt, härligt men farligt, farligt: Populärmusik i Sverige under 1900-talet (Stockholm: Natur och Kultur, 1996), 71-2; for Finland, see Pekka Jalkanen, Alaska, Bombay ja Billy Boy: Jazzkulttuurin murros Helsingissä 1920-luvulla (Helsinki: Suomen etnomusikologinen seura, 1989); Marko Tikka \& Toivo Tamminen, Tanssiorkesteri Dallapé: Suomijazzin legenda 1925-2010 (Helsinki: SKS, 2011), 14-15.

${ }^{25}$ Columbia 13439, 16068, 16220. See Strömmer (2012), 24, 28.

${ }^{26}$ Kukkonen (1998), 127-8.

${ }^{27}$ Columbia 7790. See Strömmer (2012), 23.

${ }^{28}$ For example, Leo Kauppi's lyrics to "Maailman Matti", a song about a carefree globetrotter, read that the globetrotter's mother "mourned because I didn't become a bourgeois." Columbia 13351. 
marches "Kansainvälinen" (The Internationale), "Proletaarit nouskaa" (Workers of the World Awaken) and "Vapaa Venäjä" (Free Russia). The category also included politically loaded ballads such as Punavangin laulu (The Red prisoner's song), written in the aftermath of the Finnish Civil War of $1918 .^{29}$ Interestingly, Chester did not seem to screen his imports politically, which accounts for the radical leftist undertones of some of the songs. There was clearly a niche in the market for this type of records in Finland, since they were lacking in the catalogs of Gramophone and other companies. The ideological music in these other catalogs mainly consisted of patriotic marches and other similar pieces, which only appealed to a limited audience. For example, when the German label Odeon recorded a series of military marches by a well-known Finnish military band in 1929, these records found few buyers. ${ }^{30}$ The modest appeal of ideological music was reflected in contemporary advertisements, which focused on new danceable hits and comic songs.

All in all, Chester's catalog differed interestingly from Gramophone's imports, which were distributed in Finland by the music retailer Fazer. Whereas one-third of Chester's catalog contained dance music, only onefifth of the Gramophone records represented this category (Table 6.1). Compared with Chester, Fazer apparently relied more on the kind of songs that had already been popular before World War I. Thus, the Finnish catalog of Gramophone looked as if it represented a period when gramophones and records were expensive luxury items, designed for the prosperous upper- and middle-class consumers. It mainly included classical or salon music, religious hymns and patriotic marches or songs. Gramophone's records were also different from Chester's imports in that they included Swedish-language songs, since Fazer also served the needs of Swedishspeaking consumers.

The differences between the two catalogs corresponded to the contemporary political divisions of Finland. These divisions had been exacerbated by the Finnish Civil War, fought between the socialist Reds and the nonsocialist Whites in early 1918. The war had caused 38,000 deaths and left the country deeply divided into two experience communities, White Finland and Red Finland. White Finland maintained the memory of the winners of the Civil War and bolstered the paramilitary Civil Guards, the

\footnotetext{
${ }^{29}$ For the history of these songs in Finnish America, see Saijaleena Rantanen, "Suomalaisten ‘tuplajuulaisten' laulut," Ennen ja nyt: Historian tietosanomat 17:4 (2017).

${ }^{30}$ Kukkonen (1998), 202-3.
} 
agrarian-bourgeois state and the Lutheran Church. Red Finland was the community of those defeated in the Civil War, ex-revolutionaries and their relatives, many of whom continued to be affiliated with the labor movement and shared experiences of imprisonment, terror and loss of civil rights. ${ }^{31}$ This political and experiential demarcation was reflected also in popular-music records. To put it roughly, the Gramophone Company's Finnish wholesaler Fazer offered music to White, bourgeois Finland, whereas Chester's imports were targeted at the rural folk and urban workers. This segmentation is significant considering that these two distributors accounted for almost a half of the records sold in Finland at the end of the 1920s. ${ }^{32}$

\section{The Construction of Finnishness in Dance-Music Records}

The titles of the dance-music recordings included in the Finnish catalogs of Columbia and Gramophone are revealing of the distributors' assumptions about Finnish consumer tastes. Interestingly, the words "Finland" and "Finnish" appear in only five song titles in the Chester's catalog, as compared to 12 titles in the Gramophone catalog. The titles in Chester's catalog included "Muistoja Suomenmaasta" (Memories of Finland), "Kevät Suomen metsissä" (Spring in the woods of Finland) and "Jos kaikki Suomen järvet" (If all the lakes of Finland). ${ }^{33}$ All of these tapped into nostalgia for their home country among Finnish emigrants in America. The latter two titles were also illustrative of contemporaneous Finnish music that constructed the image of the nation by relating to its seasons and nature.

Besides referring explicitly to Finland, the recorded songs named particular places or landscapes. Illustrative examples from Chester's catalog include the song titles "Inarinjärvi," and "Kallaves'," which refer to wellknown lakes, or "Punkaharju valssi," which refers to a municipality famous for its ridges. ${ }^{34}$ Songs like these continued the same kind of admiration of

\footnotetext{
${ }^{31}$ On the political division, see Miika Siironen, Valkoiset: Vapaussodan perintö (Tampere: Vastapaino, 2012) and Mervi Kaarninen's chapter in this book.

${ }^{32}$ Einari Marvia, Fazerin Musiikkikauppa 1897-1949 (Helsinki: Fazerin Musiikkikauppa, 1949); Pekka Gronow, Studies in Scandinavian-American Discography, vol. 1 (Helsinki: Suomen Äänitearkisto, 1977), 18-19; Kukkonen (1998), 111.

${ }^{33}$ Columbia 7801, 13353, 13354. See Strömmer (2012), 23-4.

${ }^{34}$ Columbia 16119, 16157, 16194. See Strömmer (2012), 25-7.
} 
natural landscape that had been common to nationally inspired music and, more generally, to nationalism in nineteenth-century Europe. ${ }^{35}$ Indeed, the song titles basically referred to the same elements of landscape, such as the lakes and forests of Southern Finland or Karelia, which had long been reproduced in published landscape images as reflecting the "Finnish" national landscape. As art historian Maunu Häyrynen has argued, this imagery "provided a mnemonic framework for patriotic sentiments," activating pride, aesthetic appreciation or melancholy, depending on the context. ${ }^{36}$

Overall, Finnish place names were far from being dominant points of reference in the record titles. In fact, they were mentioned, for example, less frequently than sailors, vagabonds and gypsies. The record producers clearly recognized that consumers not only longed for harmonious, idealized images of the nation-state but also for topics relating to the concerns of their everyday life. Moreover, these other topics imply that record distributors calculated that a mobile lifestyle and the exoticism of foreign lands would be just as appealing to Finnish consumers as to any others.

Quite interestingly, several titles in the catalogs under examination refer to Russia and Russianness, even though the relationship between the newly independent Finland and the former motherland, Russia, was tense during the interwar period. When Russia became a Soviet regime in 1917, Russophobia had been cemented as a key element of Finnish nationalism and also manifested itself in a number of Finnish comic songs published in printed form. ${ }^{37}$ Yet the imported music records of the late 1920s show few signs of anti-Russian sentiment. ${ }^{38}$ Instead, the record producers seem to have viewed Russianness as Eastern exoticism that suited popular music. For example, Chester's catalog includes titles such as "Russian Lullaby" and "Underneath the Russian moon" as well as titles that refer to the city

\footnotetext{
${ }^{35}$ See Philip V. Bohlman, The Music of European Nationalism: Cultural Identity and Modern History (Santa Barbara, CA: ABC-Clio, 2004), 83-4; Daniel M. Grimley, Grieg: Music, Landscape and Norwegian Identity (Woodbridge: Boydell, 2006).

${ }^{36}$ Maunu Häyrynen, “The Kaleidoscopic View: The Finnish National Landscape Imagery," National Identities 2:1 (2000), 16.

${ }^{37}$ Mikko-Olavi Seppälä, "Venäläissotilas suomalaisissa kupleteissa," Idäntutkimus 23:3 (2016); Sami Suodenjoki, "Popular Songs as Vehicles for Political Imagination: The Russian Revolutions and the Finnish Civil War in Finnish Song Pamphlets, 1917-1918," Ab Imperio 20:4 (2019), 241-2.

${ }^{38}$ Exceptions include Tatu Pekkarinen's comic song about Russian emigrants ("Venäläinen pakolainen," 1929). His Master's Voice A.L. 947.
} 
of Moscow and the Volga River. Some of these songs were based on Russian folk melodies. Nor was Russianness a problem for the Gramophone Company. The company's Finnish catalog contains songs like "Russian fantasy" and "A Russian medley," played by the Balalaika orchestra of Helsinki. ${ }^{39}$ Exceptional in these two pieces was the use of the balalaika, an instrument strongly associated with Russianness. ${ }^{40}$ Due to this association, the balalaika was later to disappear from among the instruments of Finnish popular music when the rise of far-right nationalism further fomented anti-Russianness in the 1930s.

Popular music records acquired a national character not only through the lyrics but more importantly through their rhythm and melody: that way they sounded familiar and "Finnish." The three best-selling Finnish popular music recordings of 1929 are illustrative of this: "Emma," "Asfalttikukka" (Asphalt Flower) and "Meren aallot" (Waves of the Sea) were all slow waltzes in a minor key. Of these three recordings, Waves of the Sea was the greatest success among Chester's imports, whereas Emma and Asphalt Flower were in Gramophone's catalog, and their sales climbed to nearly 30,000 copies. $^{41}$

The waltz Emma was essentially a love song about a treacherous girlfriend and it drew on agrarian romanticism. By contrast, Asphalt Flower, Gramophone's other hit, had an urban setting. The lyrics of Asphalt Flower told about an immoral and sexually attractive woman-in fact, the term "asphalt flower" was a euphemism for a prostitute. Compared with these songs, Waves of the Sea covered love and desire less explicitly. Having been originally produced for the Finnish-American community, Waves of the Sea related to the experiences of Finnish emigrants, who had gone through their journey to the new land. The lyrics described the similarities between the unpredictability of the sea and love life. This romantic theme was easy to identify with, explaining the song's popularity among Finns on both sides of the Atlantic.

An additional factor behind the success of Waves of the Sea was its singer Leo Kauppi, whose distinctive baritone divided the opinions of critics and was easy to imitate. ${ }^{42} \mathrm{~A}$ press commentator highlighted this imitability, and

\footnotetext{
${ }^{39}$ His Master's Voice X 3124. See Strömmer (2012), 155.

${ }^{40}$ See Suomen Sosialidemokraatti 3 October 1929, 3.

${ }^{41}$ Kukkonen (1998), 119-22, 127-8.

${ }^{42}$ Sulho Ranta, "Gram-, gram-, gramofooneja," Tulenkantajat 18 September 1929, 287; T. Pikkanen, "Gramofooni ynnä musiikki," Suomen Sosialidemokraatti 9 August 1929, 5.
} 
the bad influence of the imported gramophone records on people, by noting that one could encounter mendicant children singing Kauppi's songs in trains. ${ }^{43}$ Waves of the Sea and Kauppi's voice were also reminisced about by some respondents to a questionnaire on gramophone use. ${ }^{44}$ One informant recalled that Kauppi's songs had been among the few records owned by his neighbors, whose old gramophone had been a source of great joy to him and other children. According to the informant, he had even crafted a mock gramophone to be used in playhouse "soirées," where children "sang with creaking voices, trying to imitate Leo Kauppi." ${ }^{45}$

All in all, the three best-selling songs of 1929 have many similarities that account for their popularity. Their lyrics are short and concise, making the songs easy to memorize, even on a first hearing. All of them are made in the folk-song style, and they have short introductions followed by a refrain and an interlude. The songs are in three-quarter waltz time, and the tempo is slow. The melodies are similar as well: all the songs are in a minor key and their melody is played in legato. And since the same features were characteristic of church hymns, this made the melodies easy to learn.

The mode of presentation in these three songs was familiar to record buyers: both Waves of the Sea and Asphalt flower were played by an amateur dance band that sounded like any band in a Finnish dance hall. The group playing Waves of the Sea included an accordion, a violin, an alto saxophone and drums. The accordion naturally had a key role in these records as it was the most significant dance-music instrument of 1920s' Finland. Emma was distinctive from the other two songs as it was played by a salon orchestra, but it still sounded familiar to ordinary consumers. In the 1920s, the salon orchestras were frequent performers in cafés and restaurants in urban Finland, and they played dance-music pieces like Emma for both listeners and dancers. Combined with the content, form, arrangement and language of the musical pieces, the familiar orchestration helped listeners experience the recordings as Finnish popular music despite their transnational production chain.

\footnotetext{
${ }^{43}$ Väinö Siikaniemi, “Gramofooni ja kulttuuri,” Suomen musiikkilehti 7:15 (1929), 7.

${ }^{44}$ FLSA, KRA, Kulutus 2006-7, 310, 798.

${ }^{45}$ FLSA, KRA, Kulutus 2006-7, 276-7.
} 


\section{Free Russia as a Counterimage of an Oppressive Nation}

The Finns were divided in their attitudes toward Soviet Russia throughout the 1920s. While White Finland drew on Russophobia and saw the Bolsheviks as the great external enemy, many defeated Reds viewed the eastern neighbor differently. For them, as with many supporters of the communist movement internationally, the Soviet Union represented the fatherland of workers. ${ }^{46}$ Moreover, thousands of Finnish Reds had fled to Russia in 1918 and stayed there, playing a prominent role in the creation of the Karelian Autonomous Soviet Socialist Republic in the 1920s. ${ }^{47}$

Against this backdrop, it is striking that one of the Finnish popularmusic hits of the late 1920s was entitled "Vapaa Venäjä," in English, Free Russia. This song was based on the Russian patriotic march "Farewell of Slavianka," which had been composed by Vasily Agapkin during the First Balkan War in 1912..$^{48}$ Farewell of Slavianka had been performed mainly among Russian students during World War I, and it became a White Army anthem during the Russian Civil War. However, given that the composer Agapkin served in the Red Army, the march was also likely sung on the Bolshevik side after $1918 .{ }^{49}$ At some point, an unknown writer supplied the march with Finnish lyrics, which addressed the end of the imperial regime and the emancipation of workers in Russia. This Finnish version, titled "Vapaa Venäjä," apparently originated among Finnish Red refugees in Soviet Russia. However, by the mid-1920s, the song had also spread to workers' communities in Finland and Finnish America. ${ }^{50}$

\footnotetext{
${ }^{46}$ Tauno Saarela, Suomalainen kommunismi ja vallankumous 1923-1930 (Helsinki: SKS, 2008), 650-1.

${ }^{47}$ Markku Kangaspuro, "Finnish Project: Karelian Workers' Commune," Journal of Finnish Studies 15:1-2 (2011), 40-51.

${ }^{48}$ The American recordings of Free Russia erroneously credit Wolff Kostakowsky and not Agapkin for composing the melody. See Valentin Antonov, “Toska po Rodine'. Vokrug da okolo," Solnechnyj Veter, https://www.vilavi.ru/pes/toska/vokrug.shtml, accessed 28 May 2020.

${ }^{49}$ We thank Rustam Fakhretdinov for information on the history of "Farewell of Slavianka." See also M. D. Chertok, Russkiy voyennyy marsh: $k$ 100-letiyu marcha "Proschanie slavianki" (Moscow: Kanon+, 2012).

${ }^{50}$ The Labour Archives of Finland (TA), The Commission of Finnish Labour Tradition (TMT) 179:2953, 14; Pekka Gronow, Laulukirja: Työpäen lauluja kabdeksalta vuosikymmeneltä (Helsinki: Tammi, 1971), 57.
} 
In 1924, the record company Columbia recognized the commercial potential of Free Russia and commissioned a Finnish immigrant tenor Otto Pyykkönen to record it in New York. ${ }^{51}$ The lyrics of Pyykkönen's recording were written by Emil Rautiainen, a Finnish-American poet who later moved to the Soviet Union. Rautiainen's lyrics praise the liberation of the people from their chains and greet "the free Russia of labor, where the slaves create a new life." ${ }^{2}$ However, one verse from Rautiainen's lyrics, depicting how the workers broke "the foundations of lies" and "the power of the oppressive night," was apparently purged from the record in accordance with commercial interests. ${ }^{53}$ The song's subversiveness was also moderated by its lack of direct references to Bolshevism or the Soviet regime.

Otto Pyykkönen's Free Russia became an instant hit among Finnish Americans. A sales manager for Columbia specifically acknowledged the "very satisfactory" sales of the record in $1927,{ }^{54}$ and the frequent advertisements for the Free-Russia record in the Finnish-American press further attest to its wide circulation. ${ }^{55}$ To build on that success, Columbia also released two instrumental versions of Free Russia in America, one by an accordionist duet in 1925 and one by the Brooklyn Finnish-Socialist Club's orchestra in $1928 .{ }^{56}$

Following these developments, Charles Henry Chester decided to include Pyykkönen's record and the instrumental versions of Free Russia in his catalog for Finland (see Fig. 6.2).${ }^{57}$ This decision was eased by the fact that at this point, the march "Vapaa Venäjä" was already gaining popularity in Finland at workers' events. Beginning in 1926, a growing number of workers' choirs and orchestras included it in their repertoires. ${ }^{58}$ To explain why workers found the march so appealing, one reporter made the claim that its "lyrics and melody exceeded in majesty even those of the

${ }^{51}$ Columbia 3003-F. See Strömmer (2012), 11.

${ }^{52}$ Juha Niemelä, Finnish American Songs (Turku: Migration Institute of Finland, 2003), 14; Dmitri Frolov, "Canadian and American Finns in the GULAG," Journal of Finnish Studies 15 (2011), 166.

${ }^{53}$ Cf. Rautiainen’s lyrics for "Vapaa Venäjä," in Työväen lauluja (Superior, WI: Työmies, 1925). We thank Juha Niemelä and Saijaleena Rantanen for observing the discrepancy between the lyrics of the record and the printed song.

${ }^{54}$ Yrjö Sjöblom, "You have to educate them yourself!" Kalevainen 16 (1928), 44.

${ }^{55}$ E.g. Nykyaika 15 January 1927, 2; Punikki 15 April 1927, 10.

${ }^{56}$ Columbia 3084-F and 3174-F. See Strömmer (2012), 14, 18.

${ }^{57}$ Columbia 16058. See Strömmer (2012), 19.

${ }^{58}$ E.g. Iltalehti 9 June 1926, 2; Ilkka 6 August 1926, 1. 


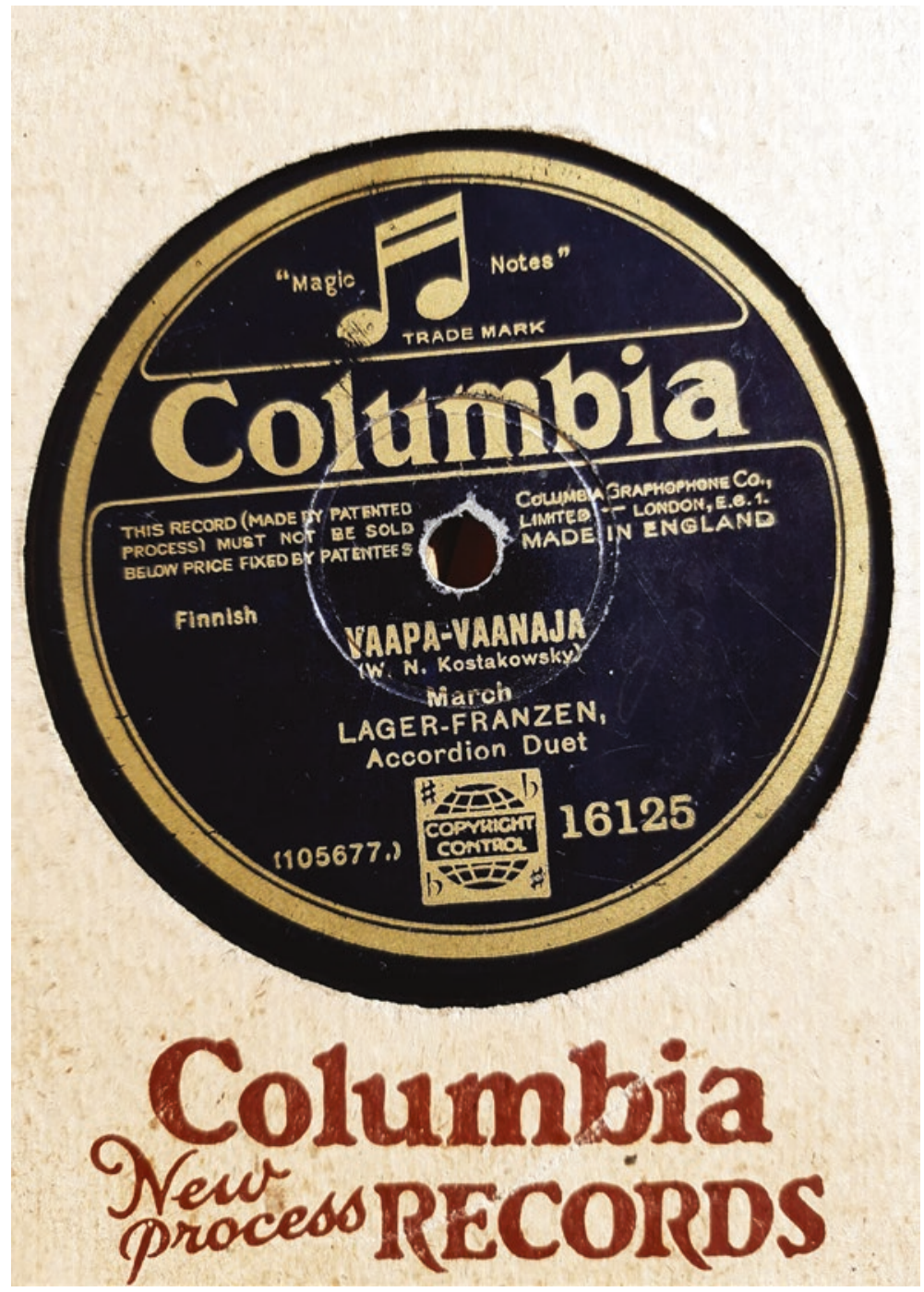

Fig. 6.2 An accordion version of Free Russia from Chester's catalog. The label title "Vaapa Vaanaja" was a comic contortion of "Vapaa Venäjä" and served to differentiate the record from the version with ideological vocals. (Photo: Marko Tikka) 
'Marseillaise." 59 This comparison was sharp-sighted, for Free Russia indeed developed into a Finnish counterpart of the "Marseillaise" in the following years. The main difference between the spread of these two marching songs was that Free Russia benefitted from records right from the beginning, whereas the trajectory of the "Marseillaise" into a transnational working-class anthem had started before the rise of the record industry. What was common to both marches was that they spread in different versions. ${ }^{60}$ As for Free Russia, this meant that the version performed at workers' events in Finland had different lyrics from Otto Pyykkönen's record. ${ }^{61}$ While these "original" lyrics likely remained the standard at workers' events even after 1928, the record, with Pyykkönen's vocals, made the march familiar to new audiences far beyond the organized workers' communities.

In both Finland and Finnish America, Free Russia especially appealed to working-class people affiliated with the labor movement. However, the contexts for distributing ideological music were essentially different in these countries. In the United States, the capitalist record industry seems to have been quite liberal toward ideological content when it looked for material that would attract Finnish-American buyers. In Finland, the distributors had to conform to a stricter ideological control. The newly independent country was still torn by the bloody Civil War, and the White winners sought to quell the leftist counterculture that survived among workers. In their anxiety over a new revolution, the bourgeois Whites eagerly banned workers' political songs as subversive propaganda. If a song appeared to praise Soviet Russia, it was especially suspicious.

When the performance of Free Russia became increasingly common in workers' events in 1926, the bourgeois commentators in the press quickly became alarmed in Finland. ${ }^{62}$ They did not even need to hear the song, as its mere name was enough to provoke suspicions about Bolshevik propaganda. ${ }^{63}$ Most importantly, bourgeois critics argued that the title and lyrics of Free Russia blatantly contradicted present conditions in the Soviet

\footnotetext{
${ }^{59}$ Pohjan Voima 6 June 1926, 3.

${ }^{60}$ For the "Marseillaise" as a workers' anthem, see Sabine Hake, The Proletarian Dream: Socialism, Culture, and Emotion in Germany, 1863-1933 (Berlin: De Gruyter, 2017), 88, 93, 126; Deborah Pearl, Creating a Culture of Revolution: Workers and the Revolutionary Movement in Late Imperial Russia (Indiana: Bloomington, 2005), 145-205.

${ }^{61}$ See Pohjan Voima 6 June 1926, 3.

${ }^{62}$ E.g. Iltalehti 9 June 1926, 2.

${ }^{63}$ Ilkka 6 August 1926, 1.
} 
Union. ${ }^{64}$ As the leading liberal newspaper Helsingin Sanomat put it, the march should not be performed in Finland but in Russia, where people truly need the freedom that the march proclaimed. ${ }^{65}$

Interestingly, Free Russia also found critics among the Social Democrats. For example, a columnist for Suomen Sosialidemokraatti associated the performance of the march with people's ignorance about the arbitrariness and terror of the Soviet government. The columnist also linked the march more generally with Russianness, as it was based on a Russian melody. Instead of Free Russia, he recommended the old Finnish workers' anthem “Työväen marssi” (The Workers' March), composed by Oskar Merikanto in 1894, as it "is stirring and more suitable on a Finnish basis." umnist's view mirrors the tendency of Finnish Social Democrats to view Soviet Russia as a threat to both Finnishness and Finnish Social Democracy. ${ }^{67}$

Despite the critique of Social Democratic commentators, Free Russia continued to enjoy popularity at workers' events. ${ }^{68}$ This had to do with the ongoing division of the labor movement into Social Democratic and Communist camps. Indeed, Free Russia seems to have become an anthem of Finnish Communists at the end of the 1920s. By playing and singing the song, communist workers could solidify their identity, strengthen their internal cohesion and protest current conditions in their country of residence. Free Russia offered an appealing counterimage to that of White Finland, the community from whose bosom they had been pushed. Hence, the case of Free Russia is revealing of how people lived out the nation and its political divides in their everyday lives. While some people used the song as a way of criticizing the oppressive Finnish nation-state, others viewed it, in contrast, to be a threat to the nation.

The leftist workers' use of Free Russia to support protest is illustrated by particular incidents in northern Finland. During these incidents, workers or working-class youth gathered on railway platforms to sing Free Russia in support of communist activists, who were either being

${ }^{64}$ E.g. Etelä-Saimaa 30 June 1927, 3.

${ }^{65}$ Helsingin Sanomat 23 June 1927, 19.

${ }^{66}$ Sasu Punanen, "Mitä Sasulle kuuluu," Suomen Sosialidemokraatti 18 June 1927, 9.

${ }^{67}$ Niko Kannisto, Vaaleanpunainen tasavalta? SDP, itsenäisyys ja kansallisen yhtenäisyyden kysymys vuosina 1918-1924 (Helsinki: Työväen historian ja perinteen tutkimuksen seura, 2016), 565.

${ }^{68}$ Eteenpäin 25 January 1928, 3; Sosialisti 30 March 1928, 5. 
transported to prison by the police or being released. ${ }^{69}$ In situations like these, the song operated as building material for an experience community as it provided leftist workers with a means to interpret and express their collective experiences of political oppression and nation-state violence.

The singing incidents on railway platforms draw our attention to the role of place and occasion in shaping experiences. Historian Peter Burke has introduced the idea of an "occasionalist" approach, which encourages historians to look closer at occasions and situations and the ways in which interaction, roles and audiences shape them..$^{70}$ During the incidents, the singing workers engaged in a dynamic interaction with other actors such as the police, railway workers, reporters and bystanders. These diverse participants responded to the singing of Free Russia very differently as the song induced among them very different experiences of the nation.

Spatiality and occasionality are likewise important factors in tracing the experiences of listening to Free Russia on a record. The spread of the imported records and gramophones multiplied the number of situations where Free Russia was played. While earlier the march was heard mainly in organized workers' events, people could now hear it on a gramophone in cafés, dance halls, trains, boats (see Fig. 6.1) and homes. ${ }^{71}$ The growing exposure to the recorded version also encouraged people to learn to sing the song or play it on an instrument. All this expanded the familiarity of the march and associated it with other popular music records, which hit the market at the same time.

The new performance contexts may have also obscured the political character of Free Russia in people's minds. This would explain why Free Russia was even played on a gramophone in a patriotic soirée of the White Civil Guard and its supporting women's organization, as a leftist newspaper ironically reported. ${ }^{72}$ On the other hand, some press commentators felt that the spread of the march into new contexts made it all the more dangerous. One columnist depicted how the playing of the tune on a gramophone in a café had made him ponder the emotional influence of Free Russia. The columnist compared the march to the Marseillaise, which

\footnotetext{
${ }^{69}$ National Archives of Finland, The Archives of the Political Police (Valpo) I, person file 147: Akseli Timonen, Overview of the Tornio delegation, 30 July-30 August 1928; Pohjan Voima 15 December 1926, 1; Perä-Pohja 9 March 1927, 5.

${ }^{70}$ Peter Burke, "Performing History: The Importance of Occasions," Rethinking History 9:11 (2005), 36, 44-9.

${ }^{71}$ E.g. Suomen Sosialidemokraatti 26 May 1929, 8; Iltalehti 15 July 1929, 4.

${ }^{72}$ Sosialisti 21 December 1929, 6.
} 
had "immensely influenced masses of men" during the French Revolution. Likewise, when Free Russia was played, some listeners were "inebriated by its tunes, having flaring eyes and emotions oriented to do battle." Hence, the columnist concluded that the march appeared a subtle form of Bolshevik agitation. ${ }^{73}$

The variations in the interpretation of Free Russia in political terms are illustrated by a response to the survey mentioned above on gramophone use. According to the respondent, his parents had acquired a gramophone in his childhood, and their record collection had included Free Russia and some other Finnish-American records. On one occasion, they had left a pile of records on a table, Free Russia lying on top, when a Civil Guard officer had visited their home. The respondent recalled that "the officer happened to lean on the Free Russia record too hard and it got broken, but it was surely an accident." While suggesting the incident to be an accident, the informant showed his awareness of the record's political character by adding that his parents "never talked politics at home." 74

In the alarm over the Free Russia records, politics amalgamated with the perceived pervasiveness of second-rate music coming from America. Press commentators repeatedly attacked Finnish-American records for their low musical quality and trifling themes. ${ }^{75}$ Underlying this criticism was the notion that many Finnish-American records were addressed to working-class audiences and some of them concerned class politics. Free Russia appeared as a showpiece of "trash music," as it was not only recorded in America by an unremarkable singer but also appeared subversive. ${ }^{76}$

On the other hand, the leftist press eagerly mocked bourgeois newspapers for their anxiety over Free Russia and other American-made records. In 1929, a columnist for Pohjan Voima noted ironically that the culprit for the viral spread of "trash music" was actually the bourgeois government, which had lowered the duties on gramophone records. The columnist stated that this decision had profoundly influenced the aural experience of the bourgeoisie:

${ }^{73}$ Kymenlaakson Sanomat 3 August 1929, 4.

${ }^{74}$ FLSA, KRA, Kulutus 2006-7, 267.

${ }^{75}$ Suomen Sosialidemokraatti 9 August 1929, 5; Tulenkantajat 18 September 1929, 13; Suomen musiikkilehti 15 (1929), 238-9.

${ }^{76}$ E.g. Tuulispä̈̈ 3 August 1929, 6-7. 
The bourgeois now suffer tremendously upon hearing the bacillary tones of "Free Russia" in their ears everywhere. The whole atmosphere of the white country $[\ldots]$ is filled by Bolshevist tones. The bourgeois no longer hear but very seldom the ultra-yearning tones of "Jager's bride. "ᄁ7

By the term "white country," the author referred to the winners of the Civil War and their political hegemony in Finland. Interestingly, the columnist also contrasted the success of Free Russia with the singspiel "Jääkärin morsian" (Jager's Bride), which had premiered in 1921. The singspiel depicted Finnish Jagers, who had gone to Germany for military training during World War I for the purpose of liberating Finland from Russia. Excerpts from Jager's Bride were recorded by several companies during the gramophone fever of 1929, and they represented the genre of nationalistic popular music on the Finnish market. ${ }^{78}$ For the leftist columnist, the comparison between Free Russia and Jager's Bride served as an analogy for the struggle between socialism and capitalism in Finland.

As the 1920s were coming to a close, Finnish authorities and rightwing activists sought to quell the spread of Free Russia by banning its performance and destroying its sheet music. ${ }^{79}$ The police and customs officials also reportedly seized shipments of Free Russia records, thus hurting the wallets of distributors like Chester. ${ }^{80}$ These measures stemmed from the rise of the radical nationalist Lapua movement, which resorted to rough justice in suppressing leftist activity and pushed the authorities to pass anti-communist legislation. ${ }^{81}$ However, among the left, the bans and seizures served to associate Free Russia even more strongly with protest against the oppressive nation-state. For one leftist commentator, the seizures illustrated what bizarre means the bourgeoisie was willing to adopt in its zeal to protect the fatherland..$^{82}$

The reported incidents concerning the distribution and performance of Free Russia support the ideas of cultural studies scholar Sara Ahmed concerning the stickiness of emotions. Ahmed emphasizes that emotions do not reside in subjects or objects but take shape as the objects of emotions

${ }^{77}$ Pohjan Voima 28 July 1929, 2.

${ }^{78}$ E.g. His Master's Voice X 3127. See Strömmer (2012), 155, 176-7, 254.

${ }^{79}$ E.g. Työpäenjärjestöjen Tiedonantaja 30 May 1929, 5, and 26 October 1929, 3; Työ 8 August 1929, 3.

${ }^{80}$ Työn Ä̈̈ni 26 July 1929, 4; Pohjan Voima 27 July 1929, 1.

${ }^{81}$ See Saarela (2008), 761-81.

82 Työväenjärjestöjen Tiedonantaja 30 May 1929, 5. 
move and circulate between bodies. ${ }^{83}$ The more widely Free Russia was spread by records and sheet music, and the more it confronted different audiences and provoked public discussion, the more emotional value was attached to it. The political charge surrounding Free Russia was hard to miss even if one viewed the record primarily in the framework of popular music, not to mention if one had political affiliations.

For many communist workers, the playing and singing of Free Russia became a means of expressing courage and unity in the face of oppression and thereby binding together their community of experience. Indeed, the song was clearly part of the phenomenon in the late 1920s where the communist movement was strongly visible in Finnish society through strikes and demonstrations. This, in turn, boosted a counterreaction and served to radicalize right-wing Whites. Considering the outraged opinion pieces about bold communists singing and playing Free Russia, ${ }^{84}$ it is not farfetched to claim that the song also consolidated the opposite community of experience, the supporters of the far-right Lapua movement, which mobilized at the turn of the 1920s and 1930s.

Just how provoked right-wing commentators were about popular music records that had anything to do with Russia is aptly illustrated by a writer to Länsi-Suomi, who wondered in 1930 why patriotic Finns wanted to listen to songs about the Volga, the Urals and the Russian moon:

The whole Russian society before and after the revolution is swarming in our modern ditties, which we listen to on our gramophones. [...] for those gramophone records, which taste like gruel, I suggest that we provide really good transportation by car to the wilderness of death. ${ }^{85}$

By urging that unwanted records should be transported to the wilderness, the writer referred to a method of abduction and intimidation adopted by far-right nationalists in their struggle against communism. In the summer of 1930, the activists of the far-right Lapua movement began to attack suspected communists by abducting and driving them to the border of the Soviet Union. By suggesting a similar treatment for records, the writer made his political stance clear and revealed the warped logic of Finnish right-wing nationalists in lumping together Russianness, communism and a bunch of gramophone records as objects of fear and hate.

${ }^{83}$ Ahmed (2004), 4-11.

${ }^{84}$ Rovaniemi 3 August 1929, 2; Fascisti 15 September 1931, 7.

${ }^{85}$ Länsi-Snomi 5 August 1930, 4. 


\section{Conclusion}

When the global gramophone fever reached Finland in the late 1920s, hundreds of thousands of consumers got to know what modern Finnish dance music was like. Nevertheless, the suppliers of this music were multinational companies such as Gramophone and Columbia, which served the needs of different ethnicities by offering them popular music in their own language. The distribution of popular-music records also required the contribution of transnational mercantile agents such as Charles Chester in Finland. Chester was involved in constructing the musical experience of the nation by selecting the imported Finnish-American records and marketing them to consumers as Finnish music. By also including in his catalog political working-class songs, he widened the idea of popular music and reached for new consumer segments.

The catalogs for Finland of Columbia and Gramophone offerings were partly designed for different audiences, but their best-selling records were very much alike: danceable waltzes with a familiar rhythm, style and orchestration. These features helped buyers to conceive of these songs as Finnish, as "our own" popular music. The idea of a Finnish popular music was also reinforced by the sheer volume of new record titles that hit the market during the lowered customs duties in 1929. As never before, consumers across the country were buying and listening to the same new releases at the same time. This generated a new collective experience of popular music, one that was intrinsically commercial and included both national and transnational dimensions. While the mere labels on the records pointed to their foreign origins and contributed to their charm, consumers could also conceive of the records as Finnish, owing to their topics, lyrics and their familiar music styles.

The rapidly growing imports of popular music records raised alarm among nationalist intellectuals regarding the corrupt musical tastes of the masses. This alarm echoed the nineteenth-century educated elite's aspirations to mold the cultural values and consumer habits of the rank and file. ${ }^{86}$ The alarm over records was also connected with politics. It was especially the Finnish-American records, which were aimed at workingclass audiences and included ideological songs, that fueled criticism about

\footnotetext{
${ }^{86}$ See Pertti Haapala, “'Rihkamakansa' - työväestö sivistyneistön silmin,” in Suomen kulttuurihistoria 3, ed. by Anja Kervanto-Nevanlinna \& Laura Kolbe (Helsinki: Tammi, 2003), 156-77; Hake (2017), 33-48.
} 
the flux of dubious low-quality music into Finland. The march Free Russia was a case in point, as its popularity among Finnish workers conjured up the threat of Soviet Russia in the minds of bourgeois and even Social Democratic commentators. However, among ordinary workers, Free Russia could evoke very different experiences and provide a counterimage to the prevailing oppressive conditions in Finland. Overall, the case of Free Russia aptly illustrates how divided was Finland still politically in the late 1920s. Even if the popular music records may have given rise to a new "Finnish" community of experience based on shared aural experiences, some records could also nourish existing political communities of experience and thereby exacerbate societal demarcations.

Open Access This chapter is licensed under the terms of the Creative Commons Attribution 4.0 International License (http://creativecommons.org/licenses/ by $/ 4.0 /$ ), which permits use, sharing, adaptation, distribution and reproduction in any medium or format, as long as you give appropriate credit to the original author(s) and the source, provide a link to the Creative Commons licence and indicate if changes were made.

The images or other third party material in this chapter are included in the chapter's Creative Commons licence, unless indicated otherwise in a credit line to the material. If material is not included in the chapter's Creative Commons licence and your intended use is not permitted by statutory regulation or exceeds the permitted use, you will need to obtain permission directly from the copyright holder.

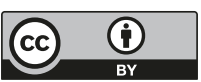

